\title{
The Effectiveness of Smart Jakarta Card Program at Islamic Senior High Schools
}

\author{
Hasyim Asy'ari ${ }^{1}$, Riqotun Nihlah ${ }^{2}$ \\ \{hasyim.asyari@uinjkt.ac.id ${ }^{1}, \underline{\text { riqotun.elmisbah@gmail.com }}^{2}$ \} \\ ${ }^{1,2}$ UIN Syarif Hidayatullah Jakarta, Indonesia
}

\begin{abstract}
This study aims at analyzing the achievements of the Smart Jakarta Card (Kartu Jakarta Pintar/KJP) program at Madrasah Aliyah at Cakung subdistrict, East Jakarta. This research uses a goal free evaluation model, which employs four steps including data collection, reduction, display, and conclusion. Data sources were obtained from the principals, KJP operator, KJP recipients, and parents/guardians of KJP recipients. Based on the results of the evaluation through questionnaires from 80 students, management deviations and use of KJP funds were found that $39.84 \%$ of the implementation of the KJP was not under KJP provisions. There are also $17.19 \%$ deviations from the KJP provisions that are positive.
\end{abstract}

Keywords: Evaluation Program, Goal Free Model, Smart Jakarta Card

\section{Introduction}

Education is important for every human being. In a popular mahfuzat (pearl of wisdom) is

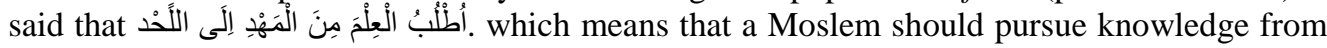
cradle to grave, meaning from birth until death [1]. In line with the mahfuzat, Indonesia also provides lifelong education opportunities as affirmed in RI Law No. 20 of 2003 concerning the National Education System, Chapter IV on the Rights and Obligations of Citizens, Parents, Society, and the Government, the first part concerning the Rights and Obligations of the State article 5 paragraph (5) which reads "Every citizen has the right to have the opportunity to improve lifelong education." Education provided must be a good quality of education. This is reaffirmed in RI Law No. 20 of 2003 concerning the National Education System, Chapter IV concerning the Rights and Obligations of Citizens, Parents, Communities, and Governments. Regarding the Rights and Obligations of the State, article 5 verse (1) reads "Every citizen has the same right to obtain a quality education." To carry out the mandate of education, the government made regulations contained in Government Regulation No. 17 of 2010 concerning Management and Implementation of Education contained in article 3 emphasized that" Management of Education is intended to guarantee; 1) community access for education services that are sufficient, equitable, and affordable, 2) the quality and competitiveness of education and its relevance to the needs and/or conditions of the community, 3) effectiveness and efficiency, and accountability in the management of education. Therefore, through education that is given properly, we hope that the Indonesian people can be more creative, innovative and more focused on determining life goals.

DKI Jakarta Province is a province that is domiciled as the Capital of the State, as well as the center of government, economic center, and autonomous region. With a variety of advantages, DKI Jakarta is the main destination for urbanization from all regions in Indonesia. 
Therefore, the province has heterogeneous community characteristics. This background makes the decentralization carried out by the DKI Jakarta government deal with the task of implementing a multi-characteristic education development. The multi-characteristics in question is the diversity of problems and needs. One of the issues that become the priority of educational development is the equal distribution of community opportunities to obtain an education. Therefore the government makes a policy on the education system contained in Regional Regulation (Perda) No. 8 of 2006 concerning the Education System explained in article 5 paragraph 1 that "Citizens aged 7 to 18 years are required to attend basic education to graduate. Then in article 16 the letter (f) confirms that the regional government is obliged to provide funds for the implementation of 12-year compulsory education especially for students from underprivileged families and neglected children.

In 2016 the APK (Gross Participation Rate) for the SMA / MA / Package C level in the DKI Jakarta area reached $73.09 \%$ and the APS (school participation rates) age 16-18 reached $70.83 \%$ whereas in 2017 both increased with the number of APK $79.51 \%$ and APS $71.5 \%$ (www.bps.go.id, downloaded on March 26, 2018). In this case, the mindset of the community regarding education is good enough by being proven through the APK and the APS. Therefore, to support the implementation of 12-year compulsory education, the Provincial Government of DKI imposed a policy of granting and Operational Assistance Costs (BOP) and Personal Education Assistance Costs (BBPP) for students from underprivileged families through the Jakarta Smart Card (KJP).

The enactment of policy certainly has obstacles while the policy is in progress. It is undeniable that KJP also has several obstacles including, namely, there are still many people who have a mentality of cash so that they are quite difficult with KJP funds coming down noncash or using ATMs, a consumptive lifestyle means that those categorized as KJP recipients spend money outside school needs such as buying daily necessities or household needs, afraid that KJP funds will be forfeited so that any given money is always spent even though the money is not forfeited and becomes their savings if the money is still there. According to online news, there are findings of misuse of KJP funds for purposes other than educational needs. Abuse is carried out in places that already have Electronic Data Capture (EDC) facilities [2]. Even according to the Governor of DKI Jakarta, Mr. Anies Baswedan, a problem related to KJP is the confusion about KJP recipients because of incompatible data [3].

\section{Methodology}

This evaluation research uses descriptive methods and goal free approach. The primary data sources in this study were person and place with procedures and data collection techniques through interviews and questionnaires. The secondary data source in this research is paper through document study activities. Researchers conducted interviews directly with the principal regarding the implementation of the KJP program, KJP operators related to technical fields and administration, students and parents/guardians of KJP recipients. The focus of the questionnaire was aimed at KJP recipient students. Quota random sampling technique is a technique used for data collection through a questionnaire. The sample used was KJP recipient students, amounting to $80 \mathrm{KJP}$ recipient students from four schools located in Cakung District. Each school has the right to choose $20 \mathrm{KJP}$ recipient students randomly. In this research, a document study is needed to obtain several important documents related to school profiles, the number of students, KJP recipient student data, KJP instructions and technical, legal/policy basis regarding KJP, and KJP requirements file. 


\section{Results and Discussion}

Evaluation as a systematic process to determine the worth, value or meaning of something [4]. Stufflebeam argues that Educational evaluation is the process of delineating, obtaining, and providing useful, information for judging alternative decisions [5]. From the opinion of Stufflebeam, it can be understood that evaluation is the process of describing, gathering and presenting information that is useful for determining alternative decisions. According to Arikunto and Jabar define evaluation is an activity to gather information about the workings of something, then the information is used to determine the right alternative in making a decision [6]. It can be concluded that evaluation is an activity to gather information on objects that are evaluated systematically that is useful for making decisions and assessing the achievement of the process.

According to Wirawan, "Programs are activities or activities designed to implement policies and implementation for activities that are not restricted" [7]. In line with this opinion, Ahuja stated: "... program is a series of organized activities designed to produce results or series of results that will have an impact on a particular problem or need" [8]. In other words, the program is a series of activities that produce results or results that will bring problems to the division of specific problems or the fulfillment of the needs. It can be concluded that the program is a separate plan or series of activities from the implementation of a policy. Thus, the evaluation program is likewise with information related to the program that is being run or has been carried out to improve the effectiveness of the program running and see the level of success of the program for decision-making purposes to obtain the next program. Evaluation programs can be used to increase the level of success associated with environmental programs by assessing whether the program is continued, postponed, developed, accepted, or replaced.

The goal free evaluation model was developed by Scriven because there is dissatisfaction with the evaluation findings that are not able to show the effect of the program being evaluated. According to Patton that evaluation is free from the objective means to collect data directly about the influence and effectiveness of the program without being limited by the narrow focus stated as the goal [7]. Patton and Scriven defined Goal-free evaluation as gathering data on a broad array of actual effects and evaluating the importance of these effects in meeting demonstrated needs [9] To evaluate the objective-free model, evaluators need to produce two items of information, namely an assessment of actual effects, and an assessment of the needs profile to be assessed [10]. Arikunto and Jabar stated that what needs to be considered in the program is how the program works, by identifying the performances that occur, both positive things -things that are expected- and negative things -which are not expected- [6].

The Jakarta Smart Card Program (KJP) is a strategic program to provide access for DKI Jakarta residents from the community who cannot afford to have a minimum education level to graduate from high school / vocational school with full funding from the DKI Jakarta Provincial Budget. The Jakarta Smart Card Program is expected to be able to encourage education without discrimination, and through this program, it is expected that educational equality will occur, especially in the Province of DKI Jakarta. The target recipients of the Personal Education Cost assistance program through the Jakarta Smart Card are students who are currently studying at the elementary, junior high, and high school /vocational school levels throughout the DKI Jakarta Province who come from underprivileged families. It is said to be poor in material and inadequate income of their parents to meet basic education needs. The basic education needs referred to include uniforms, shoes and school bags, transportation costs, 
food, and extracurricular costs. The tables below describe the negative and positive side effects of KJP implementation policy according to goal free evaluation model:

Table 1: The Negative Side Effects on KJP Implementation

\begin{tabular}{|c|c|c|c|}
\hline No & Negative Field Findings & Percentage & Conclusions \\
\hline 1. & Completion of forms by parents & $60 \%$ & \multirow{9}{*}{$\begin{array}{l}\text { There was a } \\
\text { deviation in the } \\
\text { management and use } \\
\text { of KJP funds } \\
\text { amounting to } 39.48 \% \\
\text { which did not } \\
\begin{array}{l}\text { comply with KJP } \\
\text { regulations. }\end{array}\end{array}$} \\
\hline 2. & $\begin{array}{l}\text { Determination of KJP recipients by } \\
\text { Administration (TU) }\end{array}$ & $46,25 \%$ & \\
\hline 3. & Fund collection by the bank & $16,25 \%$ & \\
\hline 4. & The use of KJP funds for SPP & $37,5 \%$ & \\
\hline 5. & $\begin{array}{l}\text { Collection of KJP recipient funds (service } \\
\text { fee) }\end{array}$ & $25 \%$ & \\
\hline 6. & $\begin{array}{l}\text { Regulation of the use of KJP funds by } \\
\text { parents }\end{array}$ & $48,75 \%$ & \\
\hline 7. & Use of KJP funds for family needs (ever) & $27,5 \%$ & \\
\hline 8. & Lagging education costs in KJP & $57,5 \%$ & \\
\hline & Average & $39,84 \%$ & \\
\hline
\end{tabular}

Based on the results of the field research, it was found that deviations in the management and use of KJP funds amounted to $39.84 \%$ which were not by KJP regulations. There were eight deviations found with explanation 1) filling out forms by parents was categorized as negative because it was highly doubtful and parents could have manipulated data as in reality they were capable categories, but the desire to receive was there so that sometimes the forms or items of questions were answered not according to conditions in fact; 2) the management of KJP recipients by the Administration section, in this case, administration section is only a mediation of the KJP program. They do not have the authority to determine but only carry out the task of inputting data following what was given by KJP registrants. All the provisions are with the school principal as the owner of the power of attorney at the school, but because the school principal does not go directly to the field regarding KJP, the KJP registrants or recipients assume that the TU determines who is entitled to receive KJP; 3) collection of funds by banks, in general administration is a natural thing in the banking world, but there is one bank that does not charge bank administrative fees for education funds or KJP or scholarships. This cannot be denied because it has become the determination or policy of each bank; 4) the use of KJP funds for SPP, according to KJP guidelines the use of KJP funds is not only for SPP only. They may use KJP funds to support the learning process so that they become the best and most outstanding students. For students who study in private schools is certainly very helpful, in addition to supporting the learning process, parents also feel relieved of the burden by having an auto-debit for SPP to the school account. But there are still double payments to 
the SPP due to lack of socialization to parents about the use of KJP; 5) levies on KJP recipient funds (service fees), these levies are not compulsorily required for KJP recipients. This levy is only sincerity and gratitude to KJP operators. Because operators there is no additional incentive regarding additional duties as KJP operators; 6) regulating the use of KJP by parents, this is done because parents are worried about the misuse of KJP funds and are afraid of KJP cards lost if held by children. In this case, parents are only limited to control. Even though the card is regulated or held by parents, the child's learning or education needs are still being met because it is the child's right. But it cannot be denied that there are also parents who abuse their KJP cards; 7) use of KJP funds for families, very few use KJP funds for family needs, for example, medical treatment, daily needs and so on. That is because the funds obtained are not sufficient for family needs and violate regulations; 8) dependence on the cost of education on $\mathrm{KJP}$, parents are very dependent on KJP funds, because it is very helpful and ease the burden of expenditure. With the KJP fund, parents and children also get additional facilities such as free boarding TransJakarta, can take a nutritional package so that the personal funds that should be allocated for education can be allocated for other things, and the child continues to get a good education.

Table 2: The Positive Side Effects on KJP Implementation

\begin{tabular}{|c|c|c|c|}
\hline No. & Positive Field Findings & Percentage & Conclusions \\
\hline 1. & $\begin{array}{l}\text { Utilization of KJP funds for productive } \\
\text { activities (venture capital) } 2.5 \%\end{array}$ & $2,5 \%$ & \multirow{5}{*}{$\begin{array}{lr}\text { There are } & 17.19 \% \\
\text { deviations } & \text { of } \\
\text { positive } & \text { KJP } \\
\text { provisions } & \end{array}$} \\
\hline 2. & $\begin{array}{l}\text { The use of KJP funds for business capital } \\
\text { (always) }\end{array}$ & $1,25 \%$ & \\
\hline 3. & invest KJP funds received (saved) & $56,5 \%$ & \\
\hline 4. & $\begin{array}{l}\text { KJP fund investment with education } \\
\text { insurance (always) }\end{array}$ & $8,75 \%$ & \\
\hline & Average & $17,19 \%$ & \\
\hline
\end{tabular}

Based on the results of the field research, there were $17.19 \%$ of the KJP deviations that were positive. This is not in the KJP guidelines or regulations, but what is done is not bad either but is creative and innovative. As for the deviations found, there are four types, namely 1) utilization of KJP funds for productive activities (venture capital), very few students use KJP funds for productive activities (venture capital) because KJP funds cannot be disbursed and have not been thought of so far that. They only use the KJP funds they get to meet their school or education needs. 2) the use of KJP funds for venture capital (always), only $1.25 \%$ of students always use KJP funds for venture capital, but after being interviewed it turns out that only to develop their interests and talents, such as drawing, so to purchase the required drawing equipment used KJP and also sold it but it was not sustainable. 3) how to invest KJP funds received (saved), KJP recipient students invest more KJP funds by saving. This makes it very easy for them to save because they automatically enter their account if the funds in the ATM card are not used and to meet the needs that are suddenly very needed, so they more often invest in savings. 4) investing KJP funds with education insurance (always), after it was 
deepened through interviews they stated they had never invested KJP funds with insurance, because insurance requires them to pay each month the agreed nominal, it is certainly very burdensome so they only invest by way of saving because saving is not enforced nominal and whenever possible.

Based on the description of the two tables above, it shows that goal free evaluation provides an opportunity for the possibility of negative and positive effects of the implementation of KJP as presented by Stevan, Arikunto and Jabar, and Wirawan, that a program can have two types of effects, namely: 1) negative side effects, that is, side effects that are not desired by the program, 2) positive effects that are the effects expected by the program designer.

\section{Conclusion}

Based on the evaluation conducted, it was concluded that the Jakarta Smart Card program at the Madrasah Aliyah level in Cakung Subdistrict, East Jakarta had not been fully effective, it needs to improve for to be well organized. There are two findings in this research, namely:

1) Negative Side Effects

Found a deviation of management and use of KJP funds by $39.84 \%$ which is not by KJP provisions. The deviations were made by parents of students, students, KJP operators and other parties related to KJP. In this deviation, it is known that the deviation occurs because it is intentional ie they know it is prohibited but it is still being done and also unintentional ie they do not know it is prohibited but they do. The deviation is still being done because there are no sanctions that make a deterrent.

2) Positive Side Effects.

There are $17.19 \%$ of the deviations from the positive KJP provisions. These deviations occur because of creative and innovative thinking among KJP recipient students, and other parties involved in KJP. Positive deviations that occur are not optimal, because KJP recipients are afraid that the funds they receive will be stopped and they are still in a consumptive mentality. With the existence and KJP, it is expected to improve the quality of education and be more innovative. This positive deviation is indeed outside the KJP rules and guidelines, but not all deviations are bad, so it is expected that a positive deviation will be able to have a positive impact on KJP recipients.

\section{Recommendation}

Based on the research findings, there are some recommendations on KJP implementation policy:

1) In registering KJP, KJP recipient schools need to be more selective, especially in terms of filing KJP applications, especially for private schools.

2) Need to socialize to parents about KJP funds they receive and the relationship between the person and the school so that the conditions for using KJP can be known by the school and KJP funds.

3) Need additional incentives from the school for KJP operators so that the program can run according to the applicable rules and it is hoped that operators can run the program or work better so that KJP is right on target.

4) Need supervision for the seller of school needs so that the price of goods sold by the actual sales price of goods, meaning that the selling price of goods is not too high. 
5) Need to legalize the school cooperative managing (Electronic Data Capture) EDC to provide the needs of students in spending KJP in schools, because if there is no regulation the existence of EDC in schools becomes illegal.

\section{References}

[1] Arifin, Luqman Hakim, dkk. Mahfudzat (Kumpulan Kata Mutiara dan Peribahasa Arab-Indonesia). Jakarta: Turos Pustaka, 2014.

[2] Rudi, Alsadad, https://megapolitan.kompas.com/read/2015/08/04/12501461/diakses pada 25 Oktober 2018.

[3] Prayoga, Fadel, https://news.okezone.com/read/2018/03/27/338/1878575/, diakses pada 25 Oktober 2018.

[4] Topno, Harshit. Evaluation of Training and Development: An Analysis of Various Models, IOSR Journal of Business anda Management, Vol. 5, 2012.

[5] Tampubolon, Manahan. Perencanaan dan Keuangan Pendidikan (Education and Finance Plan). Jakarta: Mitra Wacana Media, 2015.

[6] Arikunto, Suharsimi dan Cepi Safruddin Abdul Jabar. Evaluasi Program Pendidikan: Pedoman Teoretis Praktis Bagi Mahasiswa dan Bagi Praktis Pendidikan. Jakarta: Bumi Aksara, Cet. V, 2014.

[7] Wirawan. Evaluasi: Teori, Model, Metodologi, Standar, Aplikasi, dan Profesi. Jakarta: Raja Wali Pers, Cet. III, 2016.

[8] Yusuf, Muri. Asesmen dan Evaluasi Pendidikan Pilar Penyedia Informasi dan Kegiatan Pengendalian Mutu Pendidikan. Jakarta: Kencana, Cet. I, 2015.

[9] Cronholm, Stefan. Strategies for Information Systems Evaluation-Six Generic Types. Electronic Journal of Informations System Evaluation (EJISE), Vol 6, Issue 2, 2003.

[10] Sukardi. Evaluasi Pendidikan Prinsip dan Operasionalnya. Jakarta: Bumi Aksara, 2011, Cet. V. 